\title{
Role of Institutions in the Industrial Development of Pakistan
}

\author{
TAHIR HIJAZI
}

\section{INTRODUCTION}

This study examines why a perverse kind of industrialisation developed in Pakistan. Following independence, the Pakistan government embarked on industrialisation proclaimed as a short-cut to eradicate poverty and reduce unemployment. But after four decades, it is still considered among the poorest countries of the world, with per capita annual income of only $\$ 375$. The share of manufacturing sector in the GDP grew from a nominal base in 1947 to 19.7 percent in 1990, but it did not help raise the standard of living. Pakistan's economy grew eight-fold ${ }^{1}$ during this period whereas some other developing countries grew many times tenfold. ${ }^{2}$

Adopting a historical perspective reveals a perverse kind of industrialisation in Pakistan, which inhibits its ability to eradicate poverty [Sixth Five-year Plan 1983-88 (1982)]. By a perverse kind of industrialisation, I mean a degenerate system of industrial development which, instead of helping the national economy to expand and grow retards its process. It implies selective industrial investment which is more capitalintensive, remains import-dependent, ignores forward and backward linkages, ensures the dominance of larger oligopolists firms, produces luxury goods, does not help increase productivity, and is located in a few urban centres. This level of industry creates relatively few jobs, depends on imported materials and instead of increasing value-added at home, and puts extra pressure on foreign exchange reserves which the economy must meet by exporting primary goods. The absence of forward and backward linkages restricts opportunities for industrial expansion and larger firms relying on foreign technology employ relatively few workers; and they produce luxury goods for higher income brackets, all of which does not benefit the masses. Such perverse characteristics of industrialisation contribute little to the eradication of poverty [Lawrence (1974)].

Tahir Hijazi is Assistant Professor, International Institute of Islamic Economics, International Islamic University, Islamabad.

'GNP grew eight-fold. This may be interpreted with care as the base of GNP from where Pakistan started was very small

${ }^{2}$ South Korea grew 34 times and Japanese economy 40 times in terms of per capita income. 
Pakistan's government opted for a number of industrial policies based on different theories, but none of them helped Pakistan come out of poverty. These could be clustered into three sets of grand theories, Neoclassical, Structuralist, and Institutional transformation. An analysis of the last four decades of industrial policy in Pakistan in light of the development literature reflected the neoclassical and structuralist theory in practice. The institutional transformation theory seems to have been totally ignored. Adopting institutional transformation theory, this study seeks to identify the real sources of the perverse industrialisation process.

\section{Transforming Institutionalists}

Transforming institutionalists propose a third set of theories to explain perverse industrialisation. They focus on the behaviour patterns of central social actors. By definition, institutions comprise repetitive behaviour pattern [Seidman and Seidman (1994)]. They ground their analysis on practical reasoning, reason informed by experience, focusing on the counter-productive role of inherited institutions. They explicitly recognise the interpenetration of the institutions that shape the state with a pattern of economic development.

Transforming institutionalists define social formations in terms of institutionalised relationships, shaped by the state and law. Class power expresses itself through economic and political institutions. Class power and its institutional expression constitute two sides of the same coin.

Transforming institutionalists directed attention to the role of the state and law in the development process. For them, third world institutions perpetuate poverty. Those institutions did not arise accidentally or from the mind of a leader, but came out of the historical process. Either they were inherited from colonial rule, or were the outcome of post-colonial circumstances. Transforming institutionalists attributed the new state's failure more fundamentally to the emergence of a new fraction of the ruling oligarchythe bureaucratic bourgeoisie.

While critiquing government's industrialisation policies, economists and planners tended to ignore the role of the prevailing institutions. Nevertheless, some scholars recognised that an economic development process is always accompanied by institutional framework. Institutions comes from initial conditions and could help or restrict development. As discussed by Ranis (1989): "Institutions thus have two characteristics: one, they are an essential component of the initial conditions; and, two, they can be classified as either accommodative or obstructive in terms of the system's ability to navigate to modern growth oyer time". Institutions may thus help to keep the economy rolling or block its path.

Civil administrators played an important role in the formulation and implementation of industrial policy in Pakistan, as in many other developing countries. They comprised key role-occupants in the industrialisation process. We focused on the 
question why they made a set of policies which fostered perverse industrialisation? To explore this, we developed a problem-solving methodology which focused all institutional factors that may directly or indirectly influence the decision-making behaviours of role occupants like Pakistan's civil administrators.

Pakistan inherited its public administration system from British India. It was a system designed to rule the colony from across the world. Its objectives were to keep law and order and provide a safe haven for the rulers to fulfil their ends. After independence, Pakistan did not reform the system to meet its post-independence needs.

Public servants play a key role in the development process. They constitute the brain and the arms behind the state machinery. [Alavi (1972), pp. 291-93] asks,

"about the nature and character of those who occupy positions of authority and power within the state apparatus, the 'servants of the state'. Are they in fact masters rather than servants? If they enjoy a degree of autonomy, how far does (or can) it extend? Do they have interests of their own, independent of those of the dominant classes"?

Alavi suggests that the nature and character of the state bureaucracy establishes interests in the society quite independent of the respective classes.

\section{METHODOLOGY}

Public administrators were among the central actors in designing and implementing Pakistan's perverse industrialisation policy. In the absence of a legislature for most of the period after independence, the public administration acted on its own. To address the issue of public administrators as important social actors in the process of industrialisation, we need a methodology that enables us to study systematically all the factors likely to influence their decision-making behaviours. Therefore, we adopt the following institutionalist methodology drawn from studies of law and development. Seidman and Seidman (1994, p. 116) suggest that institutionalist theories provide us with a broader set of categories to generate middle-level propositions to explain key role-occupant's behaviour in the face of law.

\section{(a) The ROCCIPI Research Agenda}

The acronym, ROCCIPI, represents these seven categories that comprise the institutionalist research agenda: Rule, Opportunity, Capacity, Communication, Interest, Process and Ideology. Together, these seven categories purport to encompass all the possible factors likely to influence the behaviour of any particular set of role occupants. For each category, there is a need to critically assess all the middle-level explanations generated by alternative grand theories, incorporating the most fruitful into a hypothesis -a map for investigating the facts. The methodology provide us with middle-level propositions to explain the phenomenon of the perverse nature of industrialisation. 


\section{(b) Proposed Hypothesis}

Our examination of literature, together with our ROCCIPI categories, suggests a testable proposition that comprises our hypothesis for explaining Pakistan's perverse industrialisation.

Proposition: The specific characteristics of the civil administration in Pakistan hampered its ability to formulate and implement more appropriate industrialisation policies.

\section{(i) The Rules}

The existing legislation and working rules that constitute the role occupant's legal surroundings comprise the first relevant category. Does the law specify adequate implementation procedures, and provide for sufficient funds, to ensure that the government agencies responsible can perform as the law directs? The answer to these questions may provide important insights as to specific changes in the rule itself to ensure more appropriate behaviour.

\section{(ii) The Requirements of Choice}

Unless circumstances thrust the requirements of choice upon role occupants, the question of whether they consciously obey does not arise. Role occupants must make a conscious choice only when three categories of factors coincide: (a) Their environment provides them the opportunity to choose to obey or disobey. This suggests the necessity to analyse the factors that give public administrators the opportunity to engage in an industrialisation policy. (b) They have the capacity to obey, that is, they possess the skills and resources to perform the task prescribed. This underscores the importance of assessing the public administrator's training and ability to make appropriate decisions relating to industrial policy. (c) The role has been communicated to the role occupants. Probably the public administration personnel do know the rules regarding their role in industrialisation policy-making. In Table 1, a comparison is given of civil administration belonging to four countries, including Pakistan.

\section{(iii) Incentives}

Whatever the adequacy of neoclassical economic theory's identification of selfinterest as the sole explanatory category, see the theoretical model above. Material incentives plainly do constitute a powerful motive in human affairs.

\section{(iv) Process}

Whether as individuals or in collectivities, how role occupants decide to behave in response to a law depends in part upon the process by which they come to their decision. 


\section{Table 1}

Higher Civil Service Comparative Analysis:

England, Japan, South Korea, and Pakistan

\begin{tabular}{|c|c|c|c|c|}
\hline Topics & England & Japan & South Korea & Pakistan \\
\hline Statistics & $2,000^{c}$ & $1,000 \mathrm{HCS}^{\mathrm{h}}$ & & 5,000 \\
\hline . & $0.5 \%$ of C.S. & $\begin{array}{l}5,000-6,000 \text { other } \\
0.5 \% \text { of C.S. }\end{array}$ & & \\
\hline $\begin{array}{l}\text { Percent of Total } \\
\text { Labour Force }\end{array}$ & 10 percent & 9 percent & 7 percent & . 11 percent \\
\hline Recruitment & Competitive exam & Competitive exam & $\begin{array}{l}\text { Compet: exam } \\
\text { and internal } \\
\text { promotion }\end{array}$ & Competitive exam \\
\hline Promotion & $\begin{array}{l}\text { Seniority and } \\
\text { contacts }\end{array}$ & $\begin{array}{l}\text { Qualification and } \\
\text { seniority }\end{array}$ & $\begin{array}{l}\text { Qualification } \\
\text { seniority }^{d}\end{array}$ & Seniority \\
\hline Replenishment & $\begin{array}{l}\text { No early } \\
\text { retirement }\end{array}$ & $\begin{array}{l}300-400 \text { early } \\
\text { retirement }\end{array}$ & approx. 400 fired $^{\mathfrak{c}}$ & $\begin{array}{l}\text { No early } \\
\text { retirement }\end{array}$ \\
\hline $\begin{array}{l}\text { Horizontal } \\
\text { Mobility }\end{array}$ & $\begin{array}{l}\text { Very often helps } \\
\text { in promotion }\end{array}$ & Very little & Yes & $\begin{array}{l}\text { Very often helps } \\
\text { in promotion }\end{array}$ \\
\hline $\begin{array}{l}\text { Generalists or } \\
\text { Specialists }\end{array}$ & Generalists & Generalists & Highly qualified' & Generalists \\
\hline $\begin{array}{l}\text { Public and } \\
\text { Politicians } \\
\text { Hostility }\end{array}$ & $\begin{array}{l}\text { Both public and } \\
\text { politicians }\end{array}$ & $\begin{array}{l}\text { Public but not } \\
\text { much }\end{array}$ & Public & $\begin{array}{l}\text { Both public and } \\
\text { politicians }\end{array}$ \\
\hline Education & $\begin{array}{l}\text { University but not } \\
\text { in all cases }\end{array}$ & $\begin{array}{l}\text { University and } 80 \\
\text { percent from one }\end{array}$ & University & University \\
\hline Training & $\begin{array}{l}\text { Academy initially, } \\
\text { not further for } \\
\text { promotion }\end{array}$ & Not known & $\begin{array}{l}\text { Academy initially, } \\
\text { not further for } \\
\text { promotion }\end{array}$ & \\
\hline $\begin{array}{l}\text { Coordination with } \\
\text { Industry }\end{array}$ & Little & High & High & Insignificant \\
\hline $\begin{array}{l}\text { Future Careers in } \\
\text { Politics }\end{array}$ & None & Few & Not known & Insignificant \\
\hline $\begin{array}{l}\text { Constitutional } \\
\text { Protection }\end{array}$ & Yes & Not known & Not known & Yes \\
\hline
\end{tabular}

Source: Johnson (1982); Calista (1986); Heady (1960); Heady (1984); Heady (1959); Fritz Morstein Marx (ed) (1963); Heper, et al. (1980); Emmerich (1968); Jackson (1986); Laporte Robert Jr. (1984); Robert M. Gray Hockey Selvin (n.d.); Weildner (1970); and Smith (1984).

${ }^{a}$ Above this are political appointments.

bHigher civil servants.

${ }^{c} 1968$.

${ }^{\mathrm{J}}$ Information is vague about how much of weight does qualification have.

${ }^{c}$ About this number fired on corruption charges every year.

'It is not clear if professionals or generalists, but during the last 30 years more and more qualified civil servants were hired or promoted.

${ }^{g}$ Interview with a few South Korean.

${ }^{h}$ In the entire period of four decades, two big terminations took place, in which 312 and 2,000 respectively were fired. 


\section{(v) Ideology-i.e., Value and Attitudes}

Although values alone do not determine social behaviour, nevertheless, people's worldview does affect their behaviour. First, particular societal sentiments may inculcate the role occupants with value sets that dominate their choices. For that, they must investigate the actors, subjective ideology, and the extent to which it moves them to conform to the law's prescribed norm.

\section{SUMMARY AND CONCLUSION}

In Pakistan, a perverse kind of industrial development took place which did not help eradicate poverty or generate employment. Civil Administration played a key role in the formulation and implementation of policy, and is considered responsible for it. The limits of the available evidence make further research necessary before reaching final conclusions. Nevertheless, our review suggests that Pakistan's civil administrators failed to formulate and implement an appropriate industrial policy because as generalists, they lacked adequate training and the skills required to formulate appropriate measures. Their opportunity was restricted by historically shaped political, social, and economic circumstances. In the absence of strong legislative body and clearly-stated rules defining appropriate criteria and procedures, they had a free hand to format and implement measures to control the industrialisation process. The multilanguage civil service environment complicated by a file system inherited from BritishIndian civil services thwarted their ability to communicate; their personal interests led some to seek to expand their administrative empires by complicating procedures and retaining the management of industrial projects. Their decision-making process remained dominated by inputs from a powerful group of large landlords. They inheritance was the British administrative ideology, maintaining routines, which made them less flexible to consider new ideas.

\section{REFERENCES}

Alavi, Hamza (1972) The State in Post Colonial Societies. New Left Review 74 Reprinted in Goulbourne (ed) Politics and the State.

Calista, Donald J. (1986) Linking Policy Intention and Policy Implementation; The Role of the Organisation in the Integration of Human Services. Administration and Society 18: 1.

Emmerich Herbert (1968) The Scope of the Practice of Public Administration. Theory and Practice of Public Administration: Scope, Objectives and Methods. Philadelphia: American Academy of Political and Social Sciences. (Monograph.) Heady, Ferrel (1959) Bureaucracy Theory and Comparative Administration: Adm and Science Quarterly 3:4 509.

Heady, Farrel (1960) Recent Literature on Comparative Public Administration. Adm 
and Science Quarterly 5:1 134.

Heady, Farrel (1984) Public Administration: A Comparative Perspective. Third Edition.

New York and Basel: Marcel Dekker, Inc.

Heper, et al. (1980) Role of Bureaucracy and Regime Types: A Comparative Study of

Turkish and South Korea Higher Civil Servants. Adm and Society 12:2 137.

Irving Swerdlow (n.d.) The Public Administration of Economic Development. New

York, Washington, D. C., and London: Praeger Publishers.

Jackson, C. (1982) MITI and the Japanese Maracle: The Growth of Industrial Policy,

1925-75. Stanford, CA: Stanford University Press.

Laporte, Jr. Robert (1984) Administering Development. Chapter 9, pp. 252 quoted from

Burkhead. Pakistan's Development Priorities by Shahid Javed Burki and Robert

Laporte Jr. Oxford: Oxford University Press.

Lawrence, White J. (1974) Industrial Concentration and Economic Power in Pakistan.

Princeton, New Jersey: Princeton University Press.

Ranis Gustav (1989) The Role of Institutions in Transition Growth: The East Asian Newly Industrialised Countries. World Development 17:9.

Robert, M. Gray, and Hockey Selvin (n.d.) Reader in Bureaucracy: The Free Press Glencoe Illinois Robin Theobald Corruptions Development and Underdevelopment. Durham: Duke University Press.

Seidman, Ann, and Seidman Robert (1994) State and Law in the Development Process:

Problem Solving and Institutional Change in the Third World. Chapters 6 and 7. The Macmillan Press Ltd.

Smith, Bruce L. R. (1984) The Higher Civil Service, in Europe and Canada: Lessons for the United States. Washington, D. C.: The Brooking Institute.

Weildner, W. (n.d.) Development Administration in Asia 1970. Durham: Duke University Press. Includes Discussion on India and Pakistan. 


\section{Comments}

As reflected in its title, the subject matter of the paper relates to one of the most important aspects of Pakistan's economic growth. Incidentally, no substantive research has been undertaken on the subject in the context of Pakistan's economic environment and, as such, it was expected that the paper would help in filling some of the major gaps. However, the paper under discussion fails to make any serious and consistent contribution to this relatively unexplored field, with the consequence that whatever expectations may have been raised remain unfulfilled. The paper contains too many question-marks without answering any.

We may agree with the primary contention of the author that Pakistan has suffered from "a perverse kind of industrialisation", where perverse industrialisation is identified with a "degenerate stem of industrial development which, instead of helping the national economy to expand and grow, retards its process". However, numerous characteristics of perverse industrialisation elaborated by the author in his paper have been borrowed from White J. Lawrence, who presented the diagnosis of Pakistan's industrial development as early as 1974, more than twenty years ago. The author does not explore whether the characteristics identified by W. J. Lawrence still hold even after an interregnum of two decades and the industrial development which took place during this long period.

The title of the paper and its contents are somewhat dichotomous because the paper concentrates on civil (Public) administration, as the sole institution in Pakistan entrusted with policy formulation and implementation and thus responsible for the abortive industrial growth in the country. The paper does not take into account the complex nature of the decision-making process in a state or polity which inevitably has an interface with political, social, cultural, and economic agents and institutions. Of all these categories, it is generally recognised now that the role of political structure, institutions, and actors could be the most important factor in economic growth and industrial planning of a nation. In this regard, the author may refer to W. W. Rostow's classic work on the subject entitled "Politics and the Stages of Growth" published in 1971. In this important work, Rostow has tried to establish the critical role of political institutions, especially the role of the state in performing its basic functions such as provision of security, constitutional order, and welfare of the people. Rostow demonstrates very clearly that economic growth (and of course industrial development) depend very much upon the mode and the manner in which political actors and the major institutions of a country interact with each other. The behaviour of civil administration is contingent upon the nature and structure of political, legal, and economic institutions of a country. This critical aspect has been completely ignored in Mr Hijazi's paper. 
Even if civil administration is taken as the sole institution responsible for the perverse industrial development of Pakistan, the paper fails to establish any causal relationship between a given set of decisions taken by civil administration and its impact on economic growth or industrial development of the economy. In other words, the paper does not delineate in any way the linkages and mechanisms between the microlevel decisions taken by civil administration of the country and its pattern of industrial growth as it has evolved over the last five decades. It was expected that the paper would highlight the critical phases and turns in the history of industrial development of Pakistan, and how these phases were influenced by the decisions of the public administration.

One must take exception to the basic hypothesis developed in the paper which states: "The specific characteristics of the civil administration in Pakistan hampered its ability to formulate and implement more appropriate industrialisation policies". This hypothesis, which is pivotal in the paper, has been vaguely analysed. For example, the author takes up the "Rules" as one of the explanatory categories/characteristics of the civil administration. The author questions: "The existing legislation and working rules that constitute the role occupant's legal surroundings comprise the first relevant category. Does the law specify adequate implementation procedure, and provide for sufficient funds, to ensure that the government agencies responsible can perform as the law directs?" The author then adds: "The answer to this question may provide an important insight as to specific changes in the rule itself to ensure more appropriate behaviour". It is surprising, however, that the author raises this question but does not provide any answer in the context of the behaviour of civil administration and how it interacts with the "legal surroundings" of Pakistan.

The other categories or characteristics, (as part of the so-called ROCCIPI Research Agenda) such as Opportunity, Capacity, Communication, Interest, Process, and Ideology, have been discussed within a theoretical framework but hardly bear any relevance or connection to the main theme of the paper.

The paper gives the impression of a 'graft' of miscellaneous ideas unrelated to each other. For example, in Table 1, the author has given a comparative analysis of higher civil services in countries such as England, Japan, South Korea, and Pakistan, presenting a profile of recruitment, promotion, replenishment, horizontal mobility, education, training, constitutional protection, etc. However, this table does not throw any light on the possible generalisation about the relationship between public administration and industrial development of Pakistan - the subject matter of the paper.

Any meaningful analysis of industrial development in Pakistan must take into account some of the most significant underlying factors such as the following:

(i) the industrial base of the country inherited at the time of Partition;

(ii) the role of foreign capital and foreign assistance/loans and the attached conditionalities; 
(iii) the nature of industrial policies announced by the government from time to time; First Industrial Policy, 1948, Second Industrial Policy, 1959; Third Industrial Policy, 1972 (Nationalisation of Industries under the newly established Board of Industrial Management); Industrial Policy in the period 1977-88; and Industrial Policy 1988-93;

(iv) the overall development strategy from the First Plan (1955-60) to the Seventh Plan (1988-93); and the role of investment policies and priorities;

(v) fiscal incentives and tariff reforms undertaken during different phases of economic growth;

(vi) the changing balance between the private and the public sectors, and the differential impact of various factors and policies determining the private and the public sector investment; and

(vii) changes in the political and social milieu, and the shifting stance of economic policies; also the law and order situation in the country.

Having ignored the above factors, the paper vacuously attempts to defend an over-simplified hypothesis, according to which the public administration is solely responsible for the "perverse industrial growth" of the country. It eschews the fact that the state of industrial development of Pakistan is the result of a complex array of socioeconomic factors and political institutions, which have dominated and determined the pace and direction of the country's economic development during the last five decades.

Ministry of Commerce,

Aqdas Ali Kazmi Islamabad. 